\title{
SCENES Brief Presented to The Task Force on Multiculturalism
}

\author{
Penthes Rubrecht, President \\ In cooperation with: \\ Anand Vaid, Vice President; Donna Woloshyn, Past President; \\ Hilary Craig, Member-at-Large; Estelle Anthony, Member-At-Large; \\ Mary Heit, Bernice Dowhaniuk \\ On behalf of the members of SCENES (Saskatchewan Council for \\ Educators of Non-English Speakers)
}

\begin{abstract}
SCENES, a professional organization for educators in English as a Second language/Dialect (ESL/D) appreciates the adoption of the Act on Multiculturalism. The provisions therein, if consistently implemented, will make it possible for immigrant children and adults as well as Indian and Metis people to take an active part in the evolution and shaping of our Canadian society. At last people whose mother tongue is not English or French will have equal access to education and employment.

The fundamental concern that we wish to bring to the attention of this Task Force is the lack of involvement of the provincial government in the provision of language training. Consequently we are lagging far behind Quebec and Manitoba in the services we can offer.

are federal responsibilities, the Province of Saskatchewan has a mandate for education, health and social services. The provincial government must take these mandates seriously and play an active role in the co-ordination of existing ESL programmes and initiate new, more specialized programmes. It must be responsible for the development of curricula and materials and monitor and evaluate the programmes delivered in our province.

As far as the English language provision for Indian and Metis children and adults is concerned the provincial government must accept its share of the responsibility for the development of a policy on bilingual education; a policy which promotes the retention of the Indian languages and strengthens the provisions for English as a Second Language/Dialect programmes.
\end{abstract}

Even though immigration and settlement

SCENES, (Saskatchewan Council of Educators of Non-English Speakers), was founded in 1981. One of the main objectives of this professional organization is "to represent and express the professional concerns of those involved in English as a Second Language/Dialect (ESL/D) in Saskatchewan." (Constitution)

The members of SCENES wish to express their appreciation of the adoption of the Canadian Multiculturalism Act. At the same time we welcome the opportunity to submit our concerns and recommendations to the Saskatchewan Task Force on Multiculturalism. 


\section{Background}

English as a Second language programmes have been offered in the province of Saskatchewan for more than thirty years. Settlement Services such as the Open Door Societies have also been in operation for over a decade. In the past the number of immigrants who made their way to Saskatchewan was relatively small, but since the arrival of the Chilean refugees and especially since the influx of the people from South East Asia it has become obvious that the existing services both for the K-12 system and the adult population are no longer adequate to meet the needs of the newcomers to Saskatchewan. ESL teachers from all levels, administrators, government representatives and personnel from non-governmental settlement agencies met in Regina to discuss their concerns about insufficient programming, both in terms of length and diversity, as well as insufficient funding and support.

Parallel to the lack of adequate English language programmes to newcomers to Saskatchewan is the neglect of the language training for the people who have been here long before the English language was introduced to this region-the native people.

The Multiculturalism Act contains the following statements which pertain directly to our mandate:

1.c) promote the full and equitable participation of individuals and communities of all origins in the continuing evolution and shaping of all aspects of Canadian society and assist them in the elimination of any barrier to such participation;

1.i) preserve and enhance the use of languages other than English and French, while strengthening the status and use of the official languages of Canada;

2.a) ensure that Canadians of all origins have an equal opportunity to obtain employment and advancement in those [federal] institutions.

Our concerns are mainly in two areas:

A) relating to the topics of immigration and settlement in the province

(The topics of immigration and settlement will be divided into three areas: ESL programmes for adults; ESL programmes for the K-12 system; Settlement Service) and

B) relating to the provision for ESL/D delivery for Indian and Metis people

\section{The Provision of English as a Second Language Training to Adult Newcomers}

The provision of ESL training for adult newcomers has been plagued from the start by a very complex political situation. The federal and the 
provincial government annually negotiate immigration levels for Saskatchewan. Both the federal and provincial governments play a key role in the delivery of ESL based on their respective responsibilities as provided for by the BNA Act (1867). The federal government has a national mandate for employment, immigration and citizenship. It is obliged to develop and implement policy in each of these areas where national responsibility and security is involved. It is, therefore, responsible for the settlement and adjustment of all refugees and immigrants entering Canada. The provincial government is responsible for health, education and the provision of social services.

Because ESL is considered an essential service for integration of newcomers, the federal government provides funding for the implementation of ESL programmes in two major categories.

1. Occupational English is a full-time ESL programme funded by Employment and Immigration Canada (CEIC), tied to occupational needs of adult newcomers essentially headed for the workforce. Authority for the delivery of these courses is based on federal/provincial agreements. Until 1987, provision of ESL in this category was coordinated by the Department of Education. However, since occupational English is now provided through Canadian Job Strategies (CJS) funding of ESL courses is directly negotiated with the training institutions and is no longer coordinated by the Department of Education or any other official agency.

2. Citizenship development programmes are part-time ESL courses designed to enhance citizenship development and open to all adult landed immigrants and refugees seeking Canadian citizenship. Authority for provision of these courses is through a federal/provincial Citizenship/Language Instruction (CLI) agreement (1954) under the auspices of Secretary of State Canada. In 1985, another category of funding, Settlement Language Training Program (SLTP) was added to serve people with special needs who have not previously had access to ESL.

Provision of ESL is essentially regarded as a federal responsibility. However, since the provincial government has an education mandate, its responsibility is linked to curriculum standards, certification and the delivery process.

\section{Problems of Funding}

Given the recent history of federal/provincial negotiations and politics, new stress situations have been created on the delivery process. For example, in 1985 the authority for federal funding for ESL changed with the introduction of the Canadian Jobs Strategy (CJS). The federal goverments reinterpretation of its employment/training objectives had significant implications for delivery and funding. While it seemed to make more funds available the strategy created a competitive environment for funding 
in Saskatchewan which turned out to lead to less rather than more funded training opportunities. Since CEIC chooses to fund institutional ESL directly, there is no longer an opportunity for a provincial agency to coordinate and monitor programmes.

\section{Problems of Consultation and Co-ordination}

Neither of the federal departments, Employment and Immigration or Secretary of State, which fund ESL programmes, consult each other when developing new programmes and/or regulations. The lack of federally co-ordinated efforts in policy, planning and funding of ESL complicate the provision of language programmes and other services to newcomers. The members of SCENES are well aware of the need for a comprehensive national/provincial policy for ESL and we have actively participated in working towards such a policy.

\section{Efforts towards a comprehensive national/provincial ESL policy}

In 1980 TESL Ontario (Teaching of English as a Second Language) and TESL Canada, the then newly formed umbrella organization of the provincial ESL associations, organized a national symposium on South-East Asian Refugees. ESL representatives from across the country consistently raised the following concerns: "confusing funding situations, duplication of services, limited resources, lack of information, and little coordination between any of the levels of government or organizations working directly with the refugees" and immigrants (TESL Canada Newsletter 1985).

Based on the 36 presentations at the symposium a position paper was prepared under the direction of Ian Martin. It listed six principles towards a national ESL policy.

1. Universal accessibility to ESL for all newcomers to English Canada.

2. Greater flexibility and sufficiency of programmes

3. National, provincial and local coordination

4. Functional Canadian orientation and citizenship content in ESL materials.

5. Increase in support for community agencies providing settlement and language training services.

6. Recognition of the key roles of the ESL professional and the ESL profession

\section{Efforts towards a provincial ESL and settlement policy}

In 1982, SCENES Action Committee presented a brief to the Honourable Doug McArthur, Minister of Continuing Education fully endorsing the 
six principles. In addition we made recommendations for an ESL policy in Saskatchewan.

1. That a full-time ESL provincial coordinator be appointed to be responsible for the development and expansion of ESL programmes to meet the needs of all adult immigrants/refugees.

3a. That the Department of Continuing Education specifically earmark federal funds for ESL

$3 b$. That in view of the increased status and scope of ESL programmes necessitated by the increased number of people requiring English Language Training, the Department obtain adequate, additional funding at the provincial level.

Little did we know in 1982 that those were the golden years of ESL. At that time Allan Quigley in the Department of Continuing Education carried ESL responsibilties and he was asked by the Acting Associate Deputy Minister, G. Dumelie, to act as co-ordinator for ESL programmes for adults. When Allan Quigley left two years ago no new co-ordinator was appointed. Since then the Department of Education has provided minimal support and leadership in this area. Newcomers have great difficulty finding out what language programmes are available to them nor do they know what kind of training they are entitled to.

Due to lack of funding and diversified programming adult immigrants have to turn to the Literacy programmes offered by volunteers. The Regina Public Library, for example, has 250 students, 125 of them are ESL learners. This effort is to be applauded, however, the Province of Saskatchewan cannot rely on the good will of volunteers to carry out a national policy.

The funding situation has also deteriorated as has been described above. At this point we do not know how many or rather how few adult newcomers receive adequate ESL training and how much money is spent for these programmes. But we do know from the many inquiries and complaints to our members that there is a great need for more and improved services for ESL.

\section{ESL within a comprehensive settlement policy}

Settlement is a long-term process, including basic orientation, basic English as a second language courses, English for specific purposes (ESP) courses and citizenship preparation. In June of 1988 TESL Canada organized its second symposium, this time on Adult ESL and FSL (French as a second language). Representatives from all provinces (except New Brunswick, which sent no representation) raised the problem of having ESL tied so rigidly to employment. The ESL issue should be seen broadly 
as a settlement issue of fundamental importance. Language training and settlement services should be integrated in planning, delivery and funding. In addition, both federal and provincial funding has to be adequate to ensure equality of access.

\section{Recommendations}

Based on the problems and issues discussed SCENES submits the following recommendations:

1. That ESL be seen as a component in the settlement process.

2. That a Department of Multiculturalism be created which coordinates the provincial settlement services.

3. That ESL practitioners and Social Services develop special services with a cross-cultural component for adult immigrants (e.g. family violence).

4. That the Department of Education have a full-time qualified ESL specialist on staff.

5. That consultation services for all ESL Programmes, adult and K-12, be available.

6. That there will be local as well as provincial coordination of and communication among all ESL programmes.

7. That new programmes be created where necessary (e.g. pre-upgrading for $\mathrm{ABE}$ ).

8. That ESL resource centres be created in Regina and Saskatoon.

9. That materials with citizenship and provincial content be developed.

10. That a graded newspaper, published on a regular basis, be distributed to all ESL programmes free of charge.

11. That curricula be developed based on the insight gained from current research into second language acquisition and enculturalization.

12. That criteria be developed to evaluate and monitor ESL programmes.

13. That standards be developed for ESL teachers, teacher aids and daycare workers responsible for ESL pre-school children.

14. That the Department of Education and the universities set up certificate programmes for TESL.

\section{The Provision of English as a Second Language Programs to the K-12 System}

In the Education Act it is stated that every child has a right to an education. Large numbers of immigrants and refugees students wish to become students in our school system. Most of them have very few or no English skills at all. ESL programmes must be able to accommodate these students and prepare them for entry into the mainstream classes. 
In the city of Regina there are far more ESL students than the two ESL programmes (Thomson school for K-8; Balfour Collegiate for IX-XII) can accept. Parents who take their children to these centres, especially Thomson school, to seek help have to be turned away.

The Department of Education has been approached on many occasions but has turned down requests for additional programmes and additional teachers in existing programmes because of lack of funds.

At Thomson School one senior teacher and a half-time teacher are working with 80 limited English speakers (LEP) in eight grades. For this programme alone three full-time teachers and teachers' aids are urgently needed.

A different problem exists in rural schools with only a handful of children who need ESL. Since no instructional programmes are in place these children spend a lot of time in the gym or in the library, learning English by "osmosis", a method not recognized by the ESL profession.

The members of SCENES working in the K-12 system recommend:

1. That the Department of Education accept its responsibility for equality of access to education.

2. That the provincial government make funding available for ESL programmes in the K-12 system when student numbers warrant it.

3. That a coordinated effort be made on the part of settlement agencies and the schools to provide suitable placement and instruction.

4. That financial assistance be provided for rural schools to offer individual ESL training to individuals or small groups.

\section{ESL/D Delivery to Indian and Metis students}

Many of the members of SCENES are involved in the education of Saskatchewan Indian and Metis students. Many of these students, particularly in the north, come from bilingual homes or backgrounds where English is spoken as a second language, or in some instances a dialect with a distinctive accent. These students form the majority of the student population in northern Saskatchewan, and are a very significant proportion, sometimes a majority, of the population in southern schools as well.

SCENES wishes to raise the following concerns about the nature of the language education that Indian and Metis students receive:

At present there exist no provincially approved bilingual or ESL programmes for Indian and Metis students in provincial schools. This lack of a curriculum, compounded by insufficient funding and support for bilingual/ESL programmes, leads to a situation where Indian and Metis students who speak English as a second language are being placed in "remedial" or "special education" programmes. Their first language is thus viewed as a problem, not as an asset. 
Furthermore there are, at present, no provincially approved Indian languages curricula. Consequently there is a serious lack of suitable teaching materials for ESL Indian and Metis students, as well as a lack of materials that are culturally and locally relevant. There is also a lack of provincially certified Indian languages instructors and/or teachers trained in TESL (Teaching English as a second language), cross-cultural education, and language-related issues.

In cooperation and consultation with Indian and Metis political and educational organizations SCENES recommends:

1. That the provincial government arrives at a policy regarding the promotion and retention of Indian languages and the training of Indian language instructors.

2. That the provincial government authorizes the development of Indian languages curricula and ESL programmes and the materials to support these programmes.

3. That the provincial government provides start-up grants and funding mechanisms for ESL/bilingual programmes.

4. That the provincial government supports the provision of adequate training for teachers in cross-cultural education, and teaching English as a second language.

\section{THE AUTHOR}

Penthes Rubrecht came to Canada from Switzerland in 1966. She is presently director of English as a Second Language Programmes at the University of Regina.

A founding member of TESL Canada and SCENES (Saskatchewan Council for Educators of non-English Speakers) she has been involved in ESL policy issues for over ten years. 